\title{
THE SCALE OF ECOLOGICAL ACTIVITIES FOR THE MAINTENANCE OF SUSTAINABLE ENVIRONMENT IN URBAN AMATEUR GARDENS
}

Ligita BALEŽENTIENĖ, Institute of Environment and Ecology, Faculty of Forest Sciences and Ecology, Aleksandras Stulginskis University; Studentų 11, LT-53361, Akademija, Kaunas distr., Lithuania; ligita.balezentiene@asu.lt

\begin{abstract}
Though urban areas globally cover only about $3 \%$ of the earth's land surface, the UAGs have received a little attention with regards to their ecological facilities. The main aim of this study remains to assess and compare the choice of ecological management options, which guidelines to improvement of environmental-friendly forms of gardening provided by two different UAGs, e.g. Užuovejja (U) and Nemunas $(\mathrm{N})$ in Kaunas distr., central Lithuania.

The gardeners were interviewed to identify their preference of different gardening means and reasons for their ecological choices using a questionnaire $(n=60)$ containing questions about gardening behaviour were surveyed.

The interviewed gardeners differ in their commitment and motivation, their agro-ecological practices, and their habits when growing fruits and vegetables. Ecological means, e.g. self-generated compost, turf and organic fertilizer were applied in 43.3-16.7; 16.7-6.7 and $43.3-16.7 \%$ in UAGs N and U, respectively. Only 3 or $10 \%(\mathrm{~N})$ and 4 or $13.3 \%(\mathrm{U})$, of respondent regularly used chemical control means regularly. Unfortunately, only 11 or $36.7 \%(\mathrm{~N})$ and 4 or $13.3 \%(\mathrm{U})$ of respondents regularly and sometimes used biological control means. While 7 or $23.3 \%(\mathrm{~N})$ and 1 or $3.3 \%(\mathrm{U})$ of respondents apply biological control means on rare occasion. The large amount of gardeners', i.e. $63 \%(\mathrm{~N})$ and $80 \%(\mathrm{U})$ employs the natural water resources.

This study shows that choice of the urban gardeners for the farming options proceeds the act of production through the conscious manipulation of natural resources, by the means of mobilizing practices (soil improvement, pest control means, watering), as well as supported by knowledge and sustainable viewpoint. Nonetheless, local ecosystem services will support gardener motivation, enhancing knowledge of sustainable gardening, authorizing the rational use of bio-control and soil improvement products, expresses an essential need for rational usage of water and other environmental resources.
\end{abstract}

Keywords: urban allotment gardens, ecology, sustainable options

\section{INTRODUCTION}

European cities have grown rapidly since 1950th with little attention to the creation of inner city green spaces (UNFPA, 2007). More than half of the world's population lives in cities (Dye, 2008) and more than two thirds are expected to live in cities by 2050 (UN, 2010). Urban areas are 'hotspots' for energy, water and material consumption and waste production (Kaye et al. 2006; Grimm et al. 2008). Urbanisation process destroys natural ecosystems and harms the environmental quality of cities (Alberti and Marzluff, 2004). This results in areas of the city, of varying affluence and building density, with low green cover, especially trees, and with consequent negative local environmental impacts (EAA, 2011). Activity of public ecosystem services in urban areas is pointed to reduce the ecological damages enhancing resilience, health, and quality of human well-being (MA, 2003; TEEB, 2011).

Moreover, urban agriculture in the Europe has become synonymous with sustainable food systems, standing in opposition to the dominant industrial agri-food system (Barthel and Isendahl, 2013). Modern urban agriculture cannot supply food for all of a city's residents, but it can be a significant source of locally grown food. More people around the world are taking a look at urban farming, which offers to make our food as local as possible. By growing what we need near where we live, we decrease the "food miles" associated with long-distance transportation as well as encouraged to eat in season.

Another benefit of urban farming is that it can add greenery to cities, reducing harmful runoff, increasing shading, and countering the unpleasant heat island effect (Berry et al., 2013; Seto and Christensen, 2013). Urban allotment gardens as anthropogenic ecosystems contribute to agroecosystems which cover of almost half of the EU territory, and besides providing food (provisioning services), they provide important ecosystem services (regulating/maintenance services), such as amenity, biodiversity, productivity, climate amelioration, hydrological and biogeochemical cycling (MAES, 2011). Notably, beyond creating productive urban landscape UAGs provide not only additional ecosystem services such as pollinators and species diversity, cities' micro climate regulation, but also cultural services, e.g. opportunity to socialise

Copyright (C) 2017 The Authors. Published by Aleksandras Stulginskis University. This is an open-access article distributed under the terms of the Creative Commons Attribution License (CC-BY 4.0), which permits unrestricted use, distribution, and reproduction in any medium, provided the original author and source are credited. 
in a pleasant environment (Ahrné et al. 2009; MAES, 2011). Ecosystem services are defined as benefits that humans obtain from ecosystem functions (De Groot et al., 2002; MA, 2005), or as direct and indirect contributions from ecosystems to human well-being (TEEB, 2010). In general, UAGs are one of the component of urban green infrastructure, and thus compose green spaces which can serve for people to make natural reconnection with the Earth, and gain a greater appreciation for where our food comes from. Nonetheless, urban ecosystems may be seen as a broader concept in the sense that they can also include community-driven forest or river/lake areas close or within the city boundaries as well as private or allotment gardens subjected to public urban planning.

There is also little understanding of the additional challenges to the valuation in urban ecosystems, which are characterized by high complexity, heterogeneity, and fragmentation (Pickett et al., 2001). Even though urban garden spaces occupy a considerable land cover area up to a third of the total urban area, the UAGs have received a little attention with regards to their ecological services (Kendal et al., 2012). In an attempt to address these knowledge gaps this study considered the effect of ecological management options, which tips to improvement of environmental-friendly forms of gardening in UAG, which are target for halting the loss of biodiversity and the degradation of ecosystem services and restoring them (The EU..., 2011; Uren et al., 2015). We hypothesise that evaluation of the applied gardening technics and ecological intelligence in the green areas within urban allotment gardens (urban green spaces) can mitigate or offset some of the urban coming to terms with its internal contradictions can help city architects, policy-makers and practitioners better position urban agriculture within coordinated efforts for structural change, one of many means to an end rather than an end unto itself.

\section{MATERIALS AND METHODS}

Study site. For the representation the role and management practices of AGs as existing biodiversity resources occurring in the of in the central Europe, the Kaunas, the second city situated in the central part of Lithuania, was selected. To quantify the ecological scale of urban agriculture today, the two UAG, e.g. Užuovejja,U $\left(54^{\circ} 90^{\prime} 22.28^{\prime \prime} \mathrm{N}, 23^{\circ} 81^{\prime} 80.18^{\prime \prime} \mathrm{E}\right.$

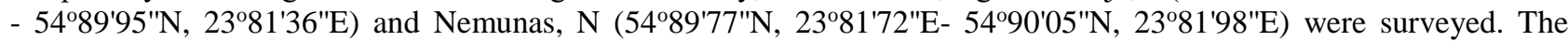
gardens are located in rather similar environment conditions on the southern bank of the Nemunas river and are bordering with botanical-zoological reservation Kamša. The boths gardens communities cover ca. 15.2 ha containing ca 200 garden plots. However these UAGs were established in different time, e.g. Nemunas, N in 1964 and Užuovejja, U in 1999.

The aforementioned UAGs are situated in the central part ( 5 hardiness zone) of Lithuania specific with a temperate climate with mean annual temperature is $5.5-7.5^{\circ} \mathrm{C}$, mean precipitation of $670 \mathrm{~mm}$, and mean summer (winter) temperature of $17^{\circ} \mathrm{C}\left(-4^{\circ} \mathrm{C}\right)$ (Galvonaite et al., 2007). Summer heats with temperatures above $30^{\circ} \mathrm{C}$ might occur. Winters can be very cold with temperatures ranging in between freezing and $-25^{\circ} \mathrm{C}$ in January and February. The total solar radiation inflow amounts to $3600 \mathrm{MJ} \mathrm{m}^{-2}$ in Lithuania. The soil is a Luvisol with a fine-sand clay loam surface soil (Calc(ar)i-Endohypogleyic Luvisol) (FAO/UNESCO, 1997).

Preference survey and sampling. It was investigated peoples' preference for different gardening means and reasons for ecological choices using a questionnaire $(n=60)$ containing questions about gardening behaviour. The questionnaire was designed to explore people's preferences for applied ecological means and their reasons for choosing the means in their allotment garden in accordance with the second MAES report (2014) on the Common International Classification of Ecosystem Services (CICES v4.3), that track the integration of environmental concerns into the Common Agricultural Policy (CAP) at EU. The questions used were generated from preliminary semi-structured interviews where a randomly sampled people was interviewed about the reasons they chose the plants in their garden. Preferences were compared with the gardening means in the gardens of 30 randomly selected respondents in each researched UAG, namely in Užuovėja and Nemunas. Empirically used gardening means were used to relate preferences to the ecological means applied by gardeners in their UA gardens.

Allotment holders were interviewed to identify additional ecosystem services to the provisioning and regulating services quantified. Questionnaires were successfully fulfilled in June-August 2014, that were part of a survey of the ecological mean applied in gardens in which addresses were randomly selected within 2 census districts stratified by different socioeconomic status and geographic location. Additional responses for the online questionnaire were sought through local community newsletters. The adult most responsible for decisions about the garden was asked to complete the questionnaire.

Statistical analysis. The distribution of the data was tested to ensure they met the assumption of normality for parametric statistical tests. The final analysis only included data from the 60 survey samples/gardens in which the preference section was completed. Less than $1 \%$ of preference ratings were missing and these were replaced by the respondent's mean. The relationship for specific means was explored by comparing respondent preferences using ANOVA.

\section{RESULTS AND DISCUSSION}

Urban gardeners clearly contribute to a sense of pleasure, well-being and benefits, and to a renewed contact with the soil, plants, and nature. We also find that UAG are places of commitment to an sustainable and organic agricultural practices. Currently, the relationship established with the garden space is not strictly about food, however it is indeed qualified as agricultural by approximately half of the interviewed gardeners. 
UAGs might achieve great cumulative result of many individual decisions about ecological behaviour choice over time that combine to determine the social, ecological and biophysical benefits provided which finally might serve/attend to increase natural capital. These benefits can vary greatly between gardens and depend on the characteristics (behaviours) of the individual applied means and technologies in them.

There were clear patterns in the preferences of respondents based on gardening knowledges in both UAGs in the preference study. The positive answers to the questionary revealed the highest gardeners number (18 respondent or $60 \%$ of respondent) familiar with average knowledge level in earlier established (in 1964) AG Nemunas (Fig. 1), where higher percent $47 \%$ of new-owners occurred during last decade than in AG Uzuoveja (18\%). It means that new gardeners of AG Nemunas accumulated poor gardening knowledge during short period. Whereas the highest content 11 person or $33 \%$ rank their knowledge level equally good or expert.

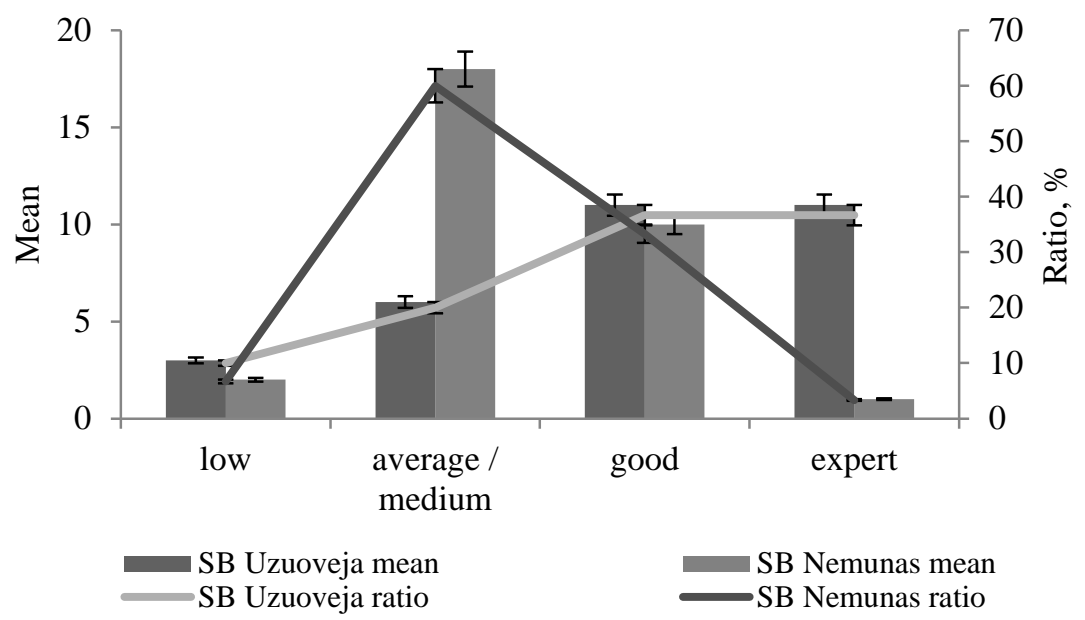

Figure 1. Comparison of level of gardening knowledge in UAG communities (mean $\pm S E ; p<0.05$ )

The level of gardening knowledge possibly impacted the completed garden performances in both AGs (Fig. 2). Higher amount of the new performances with exception of construction of cabin, terrace etc. occurred in AG Nemunas than in AG Uzuoveja. The most frequent performance $97 \%$ and $100 \%$ was planting of different plant reflecting the main preference of gardeners activity, respectively in both AG Uzuoveja and AG Nemunas. The most infrequent performance was establishment areas for wild plants /animals (9 respondent or 30\% of allotments) in AG Uzuoveja and the cultivation the terrain/area (there was no garden before) (0) in earlier established AG Nemunas. This conservation function increases the ecological value of urban allotment gardens due to maintaining or even enlarging populations of endangered species. Moreover, in the world which is becoming more urbanised, urban allotment gardens provide important benefits to humans health and wellbeing, and also are becoming an increasingly important contributors to the ecological functioning of cities by maintaining biodiversity and through the provision of ecosystem services.

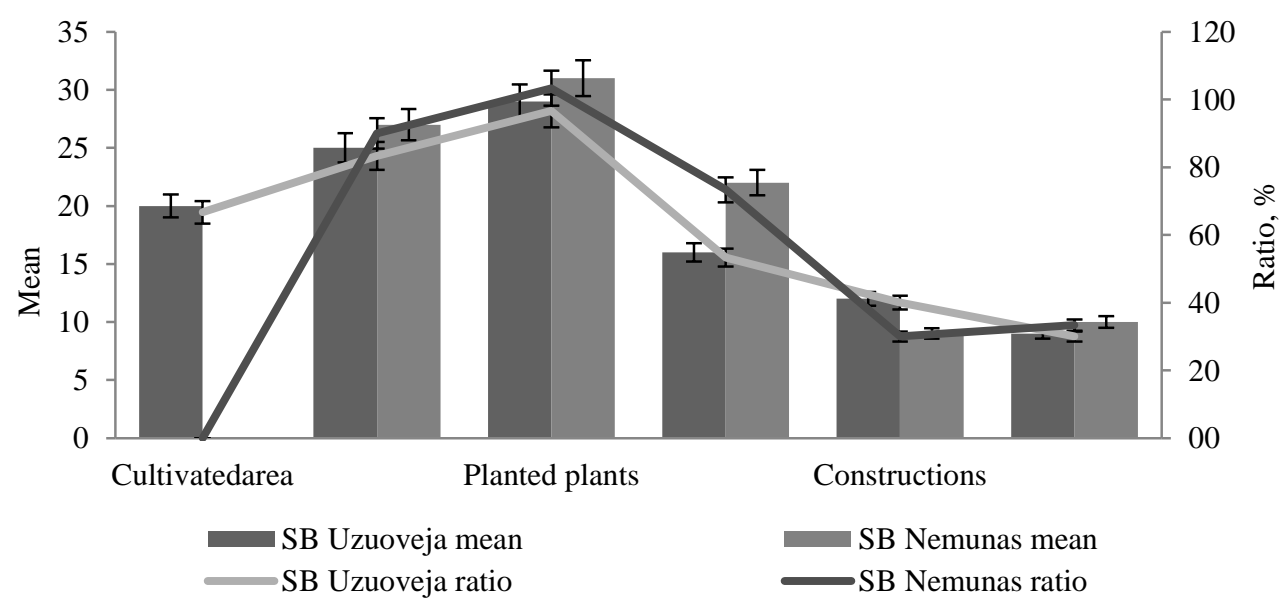

Figure 2. Garden performances $(\mathrm{p}<0.05 ;$ mean \pm SE)

These records accept that urban gardens also provide important benefits to humans in form of ecosystem service as mentioned in some studies (Guitart et al. 2012). Thereby, urban gardens contribute to enhance and maintain urban biodiversity targeting The EU 2020 Biodiversity Strategy (2011; Kowarik 2011). 
An increasing evidence that urban land uses effect profound changes in all environmental components and that humans are the main drivers of change and thus leads to maintaining or enhancing the soil fertility which is of great importance in forming and productive landscape (MEAS, 2014).

There were also clearly identifiable differences between respondents based on their preferences. The most share of respondents (27 and 22 ) declared chemical multi-range fertilizing as convincing arguments already exist regarding the need to prevent soil exhausting in both UAGs Nemunas and Uzuoveja, respectively (Fig. 3).

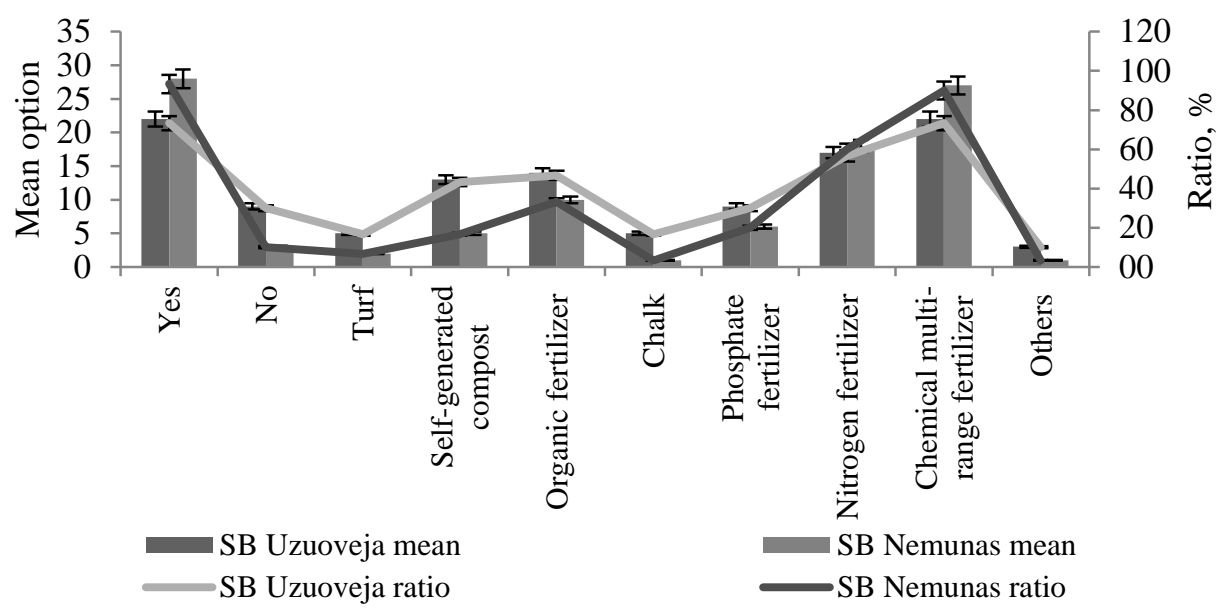

Figure 3. Improvement the soil conditions in allotment $($ mean \pm SE; $p<0.05)$

Nonetheless, chemical means compose the largest part of applied soil improvements. Ecological means, e.g. selfgenerated compost, turf and organic fertilizer / dung were applied in 43.3-16.7; 16.7-6.7 and 43.3-16.7\% in UAGs Nemunas and Uzuoveja, respectively.

There were significant differences in respondent preferences of the chemical control means in their gardens (Fig. 4). Noticeable, that the lowest number, e.g. 3 or $10 \%$ and 4 or $13.3 \%$, of respondent regularly used chemical control means regularly; sometimes -11 or $36.7 \%$ and 10 or $33.3 \%$ and on rare occasion -20 or $66.7 \%$ and 21 or $70 \%$ in UAGs Nemunas and Uzuoveja, respectively. The low usage of chemical control means in UAGs emphasise the gardener's ecological consciousness, and thus encouraged potential contribution to sustainable gardening here. Nonetheless, low part of gardeners never applied chemical control means, e.g. 5 or $16.7 \%$ and 12 or $40 \%$ in UAGs Nemunas and Uzuoveja, respectively.

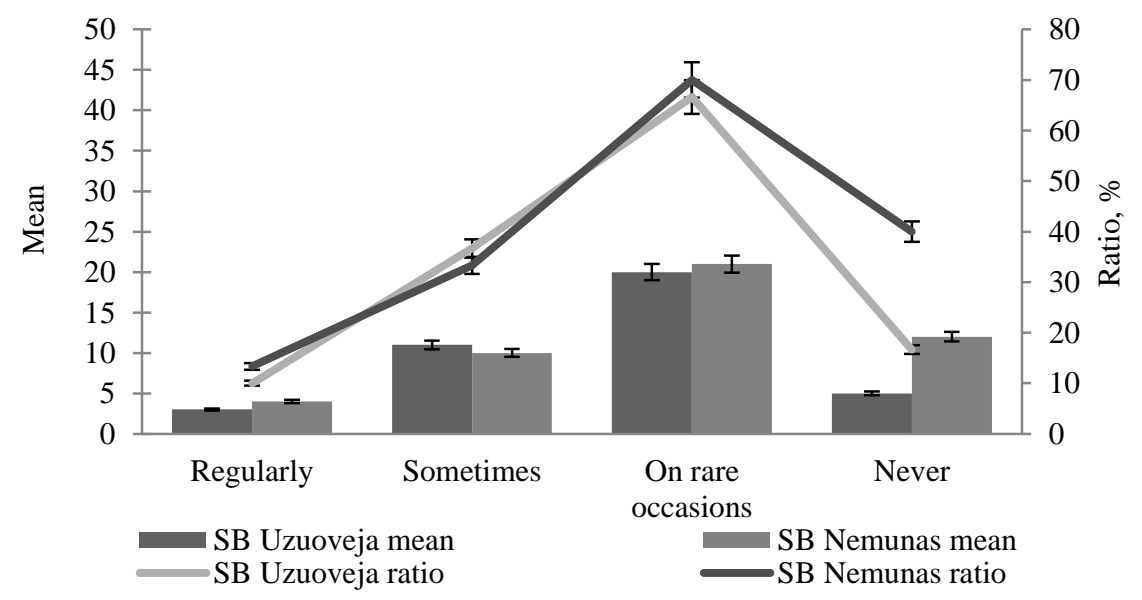

Figure 4. Application of chemical control means (insecticides, pesticides, herbicides) $($ mean \pm SE; $p<0.05)$

Application of chemical control means have a increasing impact of establishing self-sustaining populations on urban man-made sites that are subject to higher levels of disturbance. Some authors (Knapp et al., 2010; Zhao et al., 2010).) suggest that habitat changes associated with urban land uses function as key filters in urban species composition. Obviously, some species benefit from urban conditions while others experience decline.

However, some ecological improvements of urban green areas are associated with application of biological control means in UAGs (Fig. 5). Unfortunately, only 11 or $36.7 \%$ and 4 or $13.3 \%$ of respondents regularly and sometimes used biological control means in UAGs Nemunas and Uzuoveja, respectively. While 7 or $23.3 \%$ and 1 or $3.3 \%$ of respondents apply biological control means on rare occasion in UAGs Nemunas and Uzuoveja, respectively. 


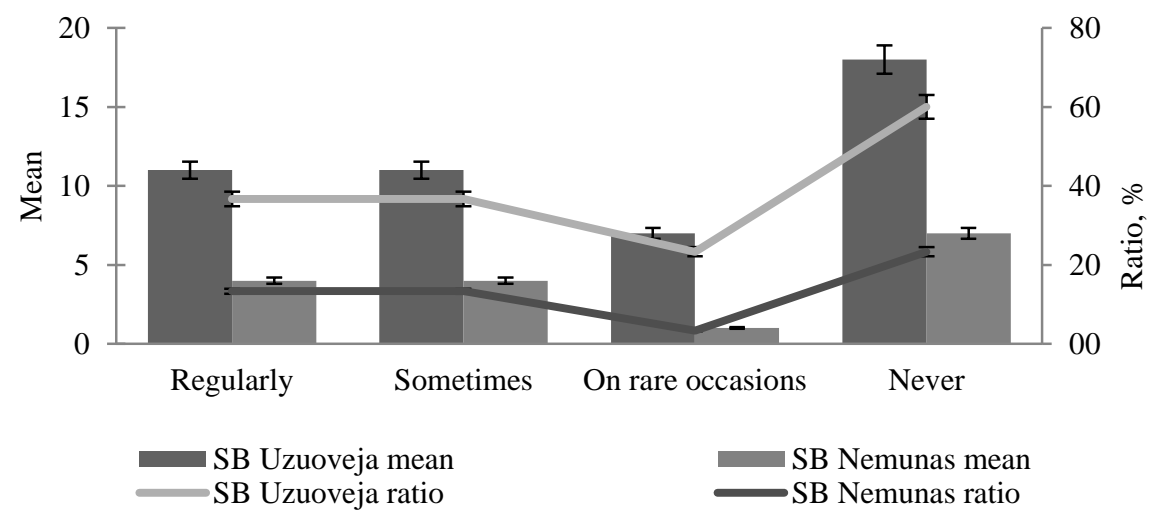

Figure 5. Application of biological control means (mean \pm SE; $p<0.05$ )

Living in recent geologic period Anthropocene (Crutzen, 1995) of being most human-influenced, or anthropogenic, based on overwhelming global evidence that atmospheric, geologic, hydrologic, biospheric and other earth system processes are now altered by humans, therefore ecological management options everywhere are of great importance.

Gardeners' choice for sustainable water supply in urban private gardens has great potential to improve ecological sustainability and human wellbeing. However, research in the area of AG Uzuoveja and Nemunas has revealed rational and simplistic view of pro-environmental behaviour which had tended to be prompt the assumption of natural resources such as pounds, neighbouring rivers etc. (Fig. 6). The large amount of gardeners', i.e. $63 \%$ and $80 \%$, employs natural water resource in AG Uzuoveja and Nemunas, respectively. Moreover, second attitude of the gardeners (33\% in AG Uzuoveja and $43 \%$ in AG Nemunas) was rainwater storage in regarding to garden design and foster a safe environment as well as surrounding nature essential element in the well-being of the city-resident.

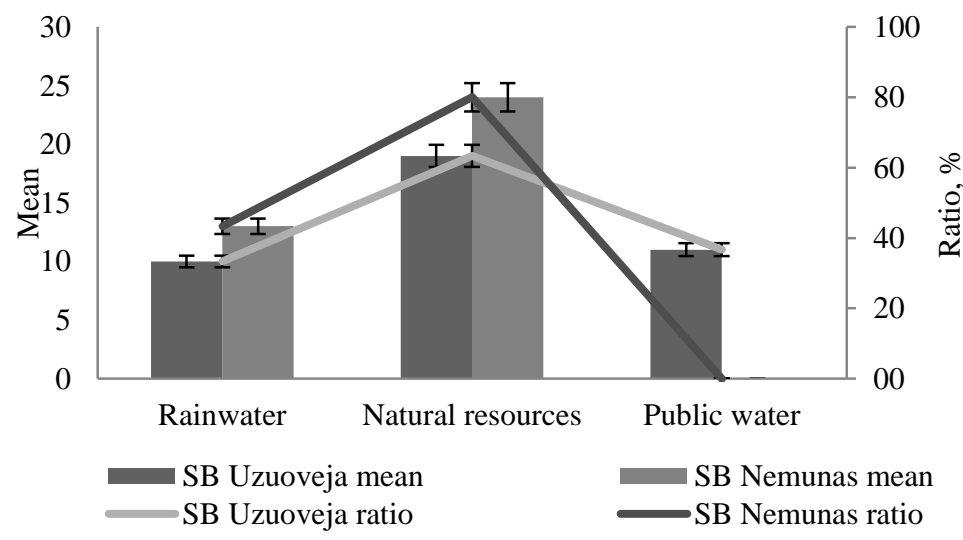

Figure 6. Choice of water supply in $U A G$ communities (mean $\pm S E ; p<0.05$ )

Following are theoretical and practical implications of the research, our findings demonstrate that urban gardening is driven not only by knowledge and functionality of the alternative gardening practices, but by broader ecological and contextual factors that create and foster a safe environment in cities partially. Furthermore, it would seem that the commitment to actually work the land is far more important in family allotment gardens. This aspect may correspond with their stronger emphasis on the dimension of food production. In general, between various conceptions the gardeners develop a real conception of sustainable gardening systems, and even of organic farming in general.

\section{CONCLUSIONS}

The interviewed gardeners differ in their commitment and motivation, their agro-ecological practices, and their habits when growing fruits and vegetables. A choice of the urban gardener for the farming options proceeds the act of production through the conscious manipulation of natural resources, by the means of mobilizing practices (soil improvement, pest control means, watering), as well as supported by knowledge and sustainable viewpoint. This study highlights that while rational individual factors appear to drive environmentally responsible behaviour, they are underpinned by deeper unconscious forces. These underlying forces which drive environmentally friendly gardening may not be so different to those driving environmentally harmful behaviour. Increased recognition of the complex union between ecological meaning and practical benefit in order to adequately understand residential sustainable standpoint and behaviour is needed. This study shows it is likely for gardens be both controlled and sustainable. Nonetheless, ecosystem services will support gardener motivation for environment-friendly practices in the urban allotment gardens, enhancing knowledge of organic and sustainable gardening, authorizing the rational use of bio-control and soil improvement products, expresses an essential need for rational usage of water and other environmental resources. 


\section{REFERENCES}

1. Ahrné, K., Bengtsson, J., Elmqvist, T., 2009. Bumble Bees (Bombus spp.) along a Gradient of Increasing Urbanization. PLoS ONE, Vol. 4, Iss. 5, pp. 5568-5574. https://doi.org/10.1371/journal.pone.0005574

2. Alberti, M. and Marzluff, J.M., 2004. Ecological resilience in urban ecosystems: linking urban patterns to human and ecological functions. Urban Ecosystems, Vol. 7, pp. 241-265.https://doi.org/10.1023/B:UECO.0000044038.90173.c6

3. Berry, R, Livesley, S. J. and Aye, L., 2013. Tree canopy shade impacts on solar irradiance received by building walls and their surface temperature. Building and Environment, Vol. 69, pp. 91-100. https://doi.org/10.1016/j.buildenv.2013.07.009

4. Crutzen, P. J., 2010. Anthropocene man. Nature, Vol. 467, pp. 1-10. https://doi.org/10.1038/467S10a

5. De Groot, R.S., Wilson, M., Boumans R., 2002. A typology for the description, classification and valuation of ecosystem functions, goods and services. Ecological Economics, Vol. 41, pp. 393-408.https://doi.org/10.1016/S0921-8009(02)00089-7

6. EEA (European Environmental Agency), 2011. Green infrastructure and territorial cohesion. The concept of green infrastructure and its integration into policies using monitoring systems. Copenhagen: EEA Technical report, 18.

7. FAO/UNESCO, 1997. Soil map of the world revised legend with corrections and updates. Technical Paper, 20. Wageningen: ISRIC, pp. 1-140.

8. Galvonaitè, A., Misiūnienè, M., Valiukas, D., Buitkuvienė, M. S. 2007. Lithuanian climate. Vilnius: Lithuanian service of hydrometeorology. 180.

9. Grimm, N.B., Faeth, S.H., Golubiewski, N.E., Redman, C.L., Wu, J.G. 2008. Global change and the ecology of cities. Science, Vol. 319, pp. 756-760. https://doi.org/10.1126/science.1150195

10. Guitart, D., Pickering, C. and Byrne, J., 2012. Past results and future directions in urban community gardens research. Urban Forestry and Urban Greening, Vol. 11, ppl. 364-373. https://doi.org/10.1016/j.ufug.2012.06.007

11. Kaye, J.P., Groffman, P.M., Grimm, N.B., Baker, L.A., Pouyat, R.V., 2006. A distinct urban biogeochemistry? Trends of Ecology Evolution, Vol. 21, pp. 192-199. https://doi.org/10.1016/j.tree.2005.12.006

12. Kendal, D., Williams, K.J.H. and Williams, N.S.G., 2012. Plant traits link people's plant preferences to the composition of their gardens. Landscape and Urban Planning, Vol. 105, pp. 34-42. https://doi.org/10.1016/j.landurbplan.2011.11.023

13. Knapp, S., Kühn, I., Stolle, J., Klotz, S., 2010. Changes in the functional composition of a central European urban flora over three centuries. Perspectives in Plant Ecology, Evolution and Systematics, Vol. 12, pp. $235-244$. https://doi.org/10.1016/j.ppees.2009.11.001

14. Kowarik, I., 2011. Novel urban ecosystems, biodiversity, and conservation. Environmental Pollution, Vol. 159, pp. $1974-1983$. https://doi.org/10.1016/j.envpol.2011.02.022

15. MA, 2003. Millennium Ecosystem Assessment: Ecosystems and human well-being. A framework for assessment. New York: Island Press. 100.

16. MAES, 2014. Mapping and assessment of ecosystems and their services. Indicators for ecosystem assessment under Action 5 of the EU Biodiversity Strategy to 2020. Luxembourg: Publications office of the EU. 82. Available at http://ec.europa.eu/environment/nature/info/pubs/ docs/brochures/2020\%20Biod\%20brochure\%20final\%20lowres.pdf (Accessed on $10 / 12 / 2017)$

17. Pickett, S.T.A., Cadenasso, M.L., Grove, J.M., Nilon, C.H., Pouyat, R.V., Zipperer, W.C., ostanza, R., 2001. Urban ecological systems: linking terrestrial ecological, physical, and socioeconomic components of metropolitan areas. Annual Review of Ecology and Systematics, Vol. 32, pp. 127-157. https://doi.org/10.1146/annurev.ecolsys.32.081501.114012

18. Seto, K.C. and Christensen, P., 2013. Remote sensing science to inform urban climate change mitigation strategies. Urban Climate, Vol. 3, pp. 1-6. https://doi.org/10.1016/j.uclim.2013.03.001

19. TEEB (The Economics of Ecosystems and Biodiversity), 2011. Manual for Cities: Ecosystem Services in Urban Management. UNEP and the European Commission.

20. The EU Biodiversity Strategy to 2020. Luxembourg: Publications Office of the European Union, 2011. 28.

21. UNFPA, 2007. State of the world population 2007—unleashing the potential of urban growth. United

22. Uren, H. V., Dzidic, P. L., Bishop B. J., 2015. Exploring social and cultural norms to promote ecologically sensitive residential garden design. Landscape and Urban Planning, Vol. 137, pp. 76-84. https://doi.org/10.1016/j.landurbplan.2014.12.008

23. Zhao, J., Oujang, Z., Zheng, H., Zhou, W., Wang, X., Xu, W., Ni, Y., 2010. Plant species composition in green spaces within the built-up areas of Beijing. Plant Ecology, Vol. 209, Iss. 2, pp. 189-204. https://doi.org/10.1007/s11258-009-9675-3 